\title{
Magnesium, vitamin D status and mortality: results from US National Health and Nutrition Examination Survey (NHANES) 2001 to 2006 and NHANES III
}

Xinqing Deng ${ }^{1}$, Yiqing Song ${ }^{2}$, JoAnn E Manson ${ }^{2,3}$, Lisa B Signorello ${ }^{3}$, Shumin M Zhang ${ }^{2}$, Martha J Shrubsole ${ }^{1}$, Reid M Ness ${ }^{4}$, Douglas L Seidner ${ }^{4}$ and Qi Dai ${ }^{1,5^{*}}$

\begin{abstract}
Background: Magnesium plays an essential role in the synthesis and metabolism of vitamin D and magnesium supplementation substantially reversed the resistance to vitamin D treatment in patients with magnesiumdependent vitamin-D-resistant rickets. We hypothesized that dietary magnesium alone, particularly its interaction with vitamin D intake, contributes to serum 25-hydroxyvitamin $D(25(\mathrm{OH}) \mathrm{D})$ levels, and the associations between serum $25(\mathrm{OH}) \mathrm{D}$ and risk of mortality may be modified by magnesium intake level.

Methods: We tested these novel hypotheses utilizing data from the National Health and Nutrition Examination Survey (NHANES) 2001 to 2006, a population-based cross-sectional study, and the NHANES III cohort, a populationbased cohort study. Serum 25(OH)D was used to define vitamin D status. Mortality outcomes in the NHANES III cohort were determined by using probabilistic linkage with the National Death Index (NDI).

Results: High intake of total, dietary or supplemental magnesium was independently associated with significantly reduced risks of vitamin D deficiency and insufficiency respectively. Intake of magnesium significantly interacted with intake of vitamin D in relation to risk of both vitamin D deficiency and insufficiency. Additionally, the inverse association between total magnesium intake and vitamin D insufficiency primarily appeared among populations at high risk of vitamin D insufficiency. Furthermore, the associations of serum 25(OH)D with mortality, particularly due to cardiovascular disease (CVD) and colorectal cancer, were modified by magnesium intake, and the inverse associations were primarily present among those with magnesium intake above the median.

Conclusions: Our preliminary findings indicate it is possible that magnesium intake alone or its interaction with vitamin D intake may contribute to vitamin D status. The associations between serum $25(\mathrm{OH}) \mathrm{D}$ and risk of mortality may be modified by the intake level of magnesium. Future studies, including cohort studies and clinical trials, are necessary to confirm the findings.
\end{abstract}

Keywords: Magnesium intake, Serum 25-hydroxyvitamin D levels, Vitamin D insufficiency, Vitamin D deficiency, Parathyroid hormone, Mortality, Colorectal cancer, Cardiovascular diseases

\footnotetext{
*Correspondence: qi.dai@vanderbilt.edu

'Department of Medicine, Division of Epidemiology, Vanderbilt University

School of Medicine, Nashville, TN 37203, USA

${ }^{5}$ Institute for Medicine and Public Health, Vanderbilt University Medical

Center, Nashville, TN 37203, USA

Full list of author information is available at the end of the article
} 


\section{Background}

Vitamin D deficiency causes rickets among children and osteomalacia in adults [1]. Many epidemiologic studies suggest that low vitamin D status may also be associated with risk of non-skeletal chronic diseases, such as, allcause mortality [2-4], type 2 diabetes [5-7], cardiovascular diseases (CVD) [8,9], and colorectal cancer [10-12]. However, findings have not been entirely consistent [13-16]. Large-scale clinical trials of vitamin D supplementation are ongoing $[13,14,17]$. Despite food fortification and dietary supplementation, some studies have observed that low vitamin D status is still relatively common in the US [18] while a large portion of the interperson variation in serum 25-hydroxyvitamin D $(25(\mathrm{OH}) \mathrm{D})$ levels is unexplained $[19,20]$.

Magnesium, the second most abundant intracellular cation, plays a critical role in the synthesis and metabolism of parathyroid hormone $(\mathrm{PTH})$ and vitamin $\mathrm{D}$ [21-23]. Previous studies have shown that the activities of three major enzymes determining 25(OH)D level [22-25] and vitamin D binding protein [23] are magnesium dependent (Figure 1). Magnesium deficiency, which leads to reduced $1,25(\mathrm{OH})_{2}$ vitamin $\mathrm{D}$ and impaired PTH response [23], has been implicated in 'magnesium-dependent vitamin-D-resistant rickets' [21]. Magnesium supplementation substantially reversed the resistance to vitamin D treatment [21]. Interestingly, a study conducted among osteoporosis patients showed much higher prevalence rates of magnesium deficiency or insufficiency among people with insufficient 25(OH)D than those with sufficient 25(OH)D [26]. Two small clinical trials of magnesium-deficient patients $[23,27]$ found that magnesium infusion alone led to a nonsignificant increase in $1,25(\mathrm{OH})_{2} \mathrm{D}$ and $25(\mathrm{OH}) \mathrm{D}$ [23] whereas magnesium infusion plus oral vitamin $\mathrm{D}$ substantially increased both serum $25(\mathrm{OH}) \mathrm{D}$ and 1,25 $(\mathrm{OH})_{2} \mathrm{D}$ [27]. These findings suggest a potential interaction between vitamin $\mathrm{D}$ and magnesium treatments

\section{Sunlight/Skin Synthesis}

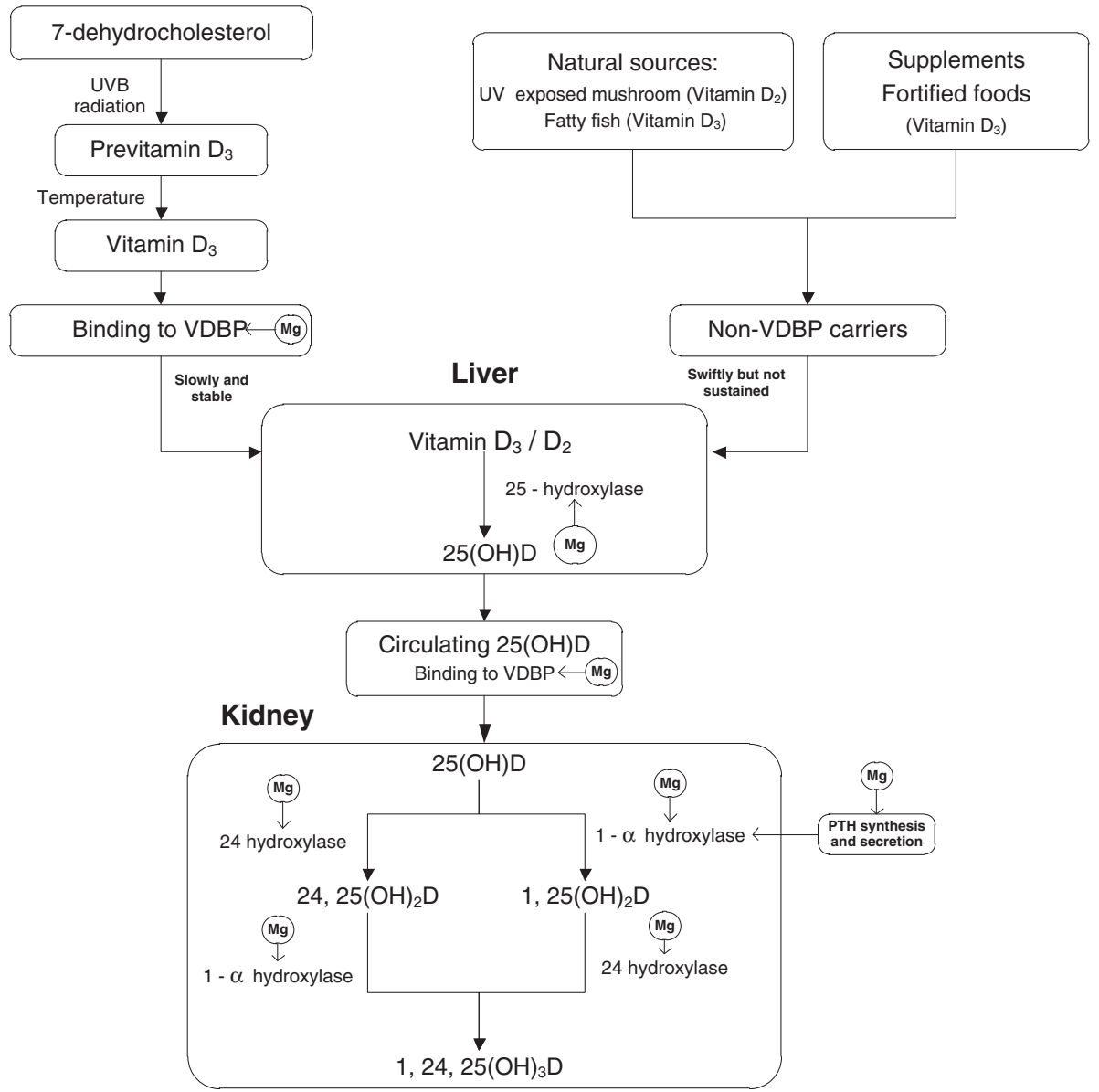

Dietary Sources

$\underline{\text { Vitamin } \mathrm{D}_{3} / \mathrm{D}_{2}}$ 
and a possible moderate effect of magnesium on $25(\mathrm{OH})$ D status.

We hypothesize that magnesium intake alone and particularly its interaction with vitamin D intake contribute to serum 25(OH)D status and tested this novel hypothesis utilizing data from the National Health and Nutrition Examination Survey (NHANES) 2001 to 2006. Furthermore, previous studies reported that serum $25(\mathrm{OHD})$ concentrations were associated with reduced risks of total mortality, particularly mortality due to colorectal cancer $[28]$ and CVD $[4,29]$. We hypothesize that the inverse associations between serum $25(\mathrm{OH}) \mathrm{D}$ and risk of mortality are modified by intake level of magnesium and tested this hypothesis using the NHANES III cohort.

\section{Methods}

\section{Participants}

The 2001 to 2006 NHANES and the NHANES III were reviewed and approved by the National Center for Health Statistics (NCHS) Institutional Review Board (IRB) (Hyattsville, MD, USA). A detailed description of the study design has been published elsewhere [30,31]. To investigate if dietary magnesium alone and its interaction with vitamin D intake contribute to serum 25 $(\mathrm{OH}) \mathrm{D}$ levels, we utilized data from the NHANES 2001 to 2006, which was conducted during years 2001 to 2006 by the NCHS of the Centers for Disease Control and Prevention (CDC) (Atlanta, GA, USA). This is a nationally representative and recent sample among the civilian, non-institutionalized US population. Thus, the status of serum $25(\mathrm{OH}) \mathrm{D}$ represents the current vitamin D status of US population. Furthermore, serum PTH data are available only in the NHANES conducted during 2003 to 2006. We limited our study population to 12257 participants aged $\geq 20$ years with serum $25(\mathrm{OH}) \mathrm{D}$, reliable dietary data, and negative for pregnancy test. However, no follow-up of mortality outcomes were conducted for NHANES 2001 to 2006. The mortality outcomes have been prospectively followed in the NHANES III cohort for which baseline data and blood collection were conducted during 1988 to 1994 among a nationally representative sample of US adults. Included in the NHANES III cohort were those aged $\geq 17$ years with 25 $(\mathrm{OH}) \mathrm{D}$ measurements $(\mathrm{n}=16819)$. The participants were followed for mortality status from baseline until December 31, 2006. Thus, we used the NHANES III cohort to examine the modifying effects of magnesium intake on the associations between serum $25(\mathrm{OH}) \mathrm{D}$ and risk of mortality. Although the NHANES III cohort is suitable for the investigation of the associations between serum 25(OH)D and mortality outcomes, no serum PTH data are available. NHANES III was approved by the National Center for Health Statistics (NCHS) Institutional Review Board (IRB) and documented consent was obtained from participants. The NCHS IRB (before 2003)/and the NCHS Research Ethics Review Board (ERB) (year 2003 and after) approved the NHANES 2001 to 2006 (protocol \#98-12 for the NHANES 2001 to 2004 and protocol \#2005-06 for the NHANES 2005 to 2006).

\section{Blood sample collection and measures of serum 25(OH)D} Over $88 \%$ of the 2001 to 2006 NHANES participants and about $90 \%$ of the NHANES III participants donated a spot blood sample. Measurements of serum 25(OH)D were performed at the $\mathrm{NCH}, \mathrm{CDC}$, Atlanta, GA using a radioimmunoassay (RIA) kit (Diasorin Inc., Stillwater MN, USA) [32] and the coefficients of variations (CV) were $13 \%$ to $19 \%$ in the NHANES III and $10 \%$ to $13 \%$ in the NHANES 2001 to 2006 [29]. Serum PTH concentrations were measured using the ECL/Origen electrochemiluminescent process (Elecsys 1010 system, Roche Diagnostics, Indianapolis, IN, USA) and CV was less than $10 \%$. Data were available only for the NHANES 2003 to 2006.

\section{Outcomes}

We have utilized the cut-off points as defined in the recently issued Institute of Medicine (IOM) report to define vitamin D deficiency and insufficiency [33]. We classified the participants in the NHANES 2001 to 2006 into the following three categories: (1) participants who had IOM recommended vitamin D level (serum $25(\mathrm{OH})$ $\mathrm{D} \geq 20 \mathrm{ng} / \mathrm{ml}(50 \mathrm{nmol} / \mathrm{l})$ ); (2) participants who had insufficient vitamin $D$ (serum $25(\mathrm{OH}) \mathrm{D} \geq 12 \mathrm{ng} / \mathrm{ml}$ (30 nmol/l) but below $20 \mathrm{ng} / \mathrm{ml}(50 \mathrm{nmol} / \mathrm{l})$ ); and (3) participants who had vitamin $\mathrm{D}$ deficiency (serum 25 $(\mathrm{OH}) \mathrm{D}<12 \mathrm{ng} / \mathrm{ml}(30 \mathrm{nmol} / \mathrm{l}))$. In addition to Institute of Medicine's recommendation, the other reason we used $20 \mathrm{ng} / \mathrm{ml}$ as the cut-off point is that the median value of serum 25(OH)D for the NHANES 2001 to 2006 was $21.0 \mathrm{ng} / \mathrm{mg}$, which is very close to $20 \mathrm{ng} / \mathrm{ml}$.

In the NHANES III cohort, mortality outcomes were determined by using probabilistic linkage with the $\mathrm{Na}$ tional Death Index (NDI). For mortality due to CVD or colorectal cancer, participants who died of other diseases or were not known deceased, were censored at the date of death or December 31, 2006, whichever was earlier.

\section{Nutrient intake assessments}

Daily dietary intake data were obtained from 24-h dietary recalls and 30-day supplement interviews, which are described in detail elsewhere [34]. Only one 24-h recall was conducted in NHANES III and from 2001 to 2002. To keep intake information consistent through the study period only the first dietary recall for all subjects was utilized in the present analysis. Only dietary recall data with a status of 'reliable' were used in the analysis. 
Supplemental doses and intakes of magnesium, vitamin $\mathrm{D}$, and calcium were obtained from the response to a dietary supplement questionnaire.

\section{Statistical analysis}

We performed statistical analyses using PROC Survey in SAS 9.2 software (SAS Institute, Cary, NC, USA) to estimate variance after incorporating the weights for the sample population in NHANES.

Covariates were compared among three groups with differing vitamin $\mathrm{D}$ status (Table 1). Any covariate that significantly differed among groups was considered as a potential confounding factor. In particular, those confounders that altered the estimate of association by $10 \%$ or more were retained in the final models (see footnotes to Tables 2 and 3). Other factors, such as use of phosphorus, potassium, and retinol, did not materially alter the risk estimates. Multivariate adjusted odds ratios (ORs) and 95\% confidence intervals (CIs) for vitamin D deficiency and insufficiency were calculated. Stratified analyses by potential effect modifiers and tests for multiplicative interactions using the Wald test were conducted.

Hazard ratios (HR) were estimated in Cox proportional hazard regression models to examine whether the associations between serum 25(OH)D and risk of mortality differed by intake level of total magnesium, using the data from the NHANES III cohort. The same cut-off points for serum $25(\mathrm{OH}) \mathrm{D}$ were used as those in the published report [28]. We adjusted for the same confounding factors as we did for vitamin D deficiency and insufficiency analyses. All reported $P$ values were two-sided. $P$ values of $<0.05$ were considered statistically significant in all analyses.

In Table 4, we present the associations between serum $25(\mathrm{OH}) \mathrm{D}$ and risk of mortality within two strata $(<264$ $\mathrm{mg} /$ day and $\geq 264 \mathrm{mg} /$ day) of magnesium intake. However, this is only for data presentation purpose. In statistical modeling, we have used continuous variables for both serum 25(OH)D and intakes of magnesium in the tests for interactions between serum 25(OH)D and intakes of magnesium in relation to total mortality, mortality due to cardiovascular disease and mortality due to colorectal cancer. We chose $264 \mathrm{mg} /$ day as the cut-off point presented in Table 4 based on both statistical power consideration and biological support. We have a limited sample size for colorectal cancer mortality outcome. By using a median magnesium intake of 264 $\mathrm{mg} /$ day, we could maximize the sample size, and, thus, the power to detect association between vitamin D levels and mortality outcomes in both strata. Furthermore, 264 $\mathrm{mg} /$ day is very close to the $265 \mathrm{mg} /$ day, the estimated average requirements (EAR) for women and so it gave us the opportunity to evaluate the relationship to the EAR [35].

\section{Results}

Selected demographic characteristics and potential confounding factors by the three categories of serum 25 $(\mathrm{OH}) \mathrm{D}$ status are shown in Table 1. Compared to the Estimate Average Requirements (EAR, intake levels for vitamin D (400 IU/day) and magnesium (330 mg/day) recommended by the US Food and Nutrition Board of the Institute of Medicine), the vitamin D normal group generally met the recommended intake levels for both vitamin $\mathrm{D}$ and magnesium whereas the average intake levels of these nutrients were significantly lower in the vitamin D-insufficient group and much lower among the vitamin D-deficient group.

After adjusting for confounding factors, the ORs (95\% CI) for vitamin D deficiency and insufficiency were 0.10 (0.06 to 0.17$)$ and 0.37 (0.27 to 0.51$)$ comparing the highest quartile intake of total vitamin $D$ versus the lowest $\left(P_{\text {trend }}<0.001\right)$ (Table 2$)$. The corresponding ORs (95\% CI) were 0.34 (0.21 to 0.56 ) and 0.62 (0.46 to 0.82 ) for total magnesium intake $\left(P_{\text {trend }}<0.001\right)$, respectively. In addition, we found that both dietary and supplemental intakes of vitamin D and magnesium were significantly inversely associated with risks of vitamin D deficiency and insufficiency.

In stratified analyses by intake of vitamin $\mathrm{D}$ and other factors related to vitamin D status (Table 3), we found intake of magnesium significantly interacted with intake of vitamin $\mathrm{D}$ in relation to both vitamin $\mathrm{D}$ deficiency $\left(P_{\text {interaction }},<0.001\right)$ and insufficiency $\left(P_{\text {interaction }},<0.001\right)$. The inverse association between magnesium intake and risk of vitamin D deficiency only appeared significant among those older than 50 years or with serum PTH level being in the highest or lowest tertile category. Meanwhile, the inverse associations between magnesium intake and risk of vitamin D insufficiency were statistically significant only among people at high risk of vitamin $\mathrm{D}$ insufficiency, such as those whose samples were collected during winter (at southern latitude), those with vitamin $\mathrm{D}$ intake below the median, women, nonHispanic Blacks, obese individuals or those with the PTH levels in the highest tertile.

As reported previously, high levels of serum 25(OH)D were associated with a reduced risk of mortality due to all-cause CVD [4,29,36], and colorectal cancer [28]. We found that the inverse associations for higher serum 25 $(\mathrm{OH}) \mathrm{D}$ with risks of total mortality and mortality due to CVD were only statistically significant among those with magnesium intake above the median (Table 4). Although the test for interaction was not statistically significant for total mortality, it was statistically significant for mortality due to CVD ( $\left.P_{\text {interaction }}, 0.03\right)$. Sample size was small for mortality due to colorectal cancer. None of the associations, including the main association, were statistically significant. However, the association pattern in 
Table 1 Selected characteristics of the study participants by serum 25(OH)D levels, National Health and Nutrition Examination Survey (NHANES) 2001 to 2006

\begin{tabular}{|c|c|c|c|c|}
\hline Characters $^{\mathrm{a}}$ & Normal, $n=6962$ & Insufficiency, $\mathrm{n}=3620$ & Deficiency, $\mathrm{n}=1575$ & $P$ value $^{\mathrm{b}}$ \\
\hline Serum 25(OH)D (ng/ml), mean (SE) & $28.5(0.2)$ & $16.1(0.2)$ & $8.8(0.1)$ & $<0.001$ \\
\hline Age (years), mean (SE) & $47.0(0.4)$ & $46.7(0.4)$ & $46.2(0.6)$ & $<0.001$ \\
\hline Male, n (\%) & $3711(51.2)$ & $1833(47.7)$ & $696(38.4)$ & $<0.001$ \\
\hline Body mass index $\left(\mathrm{kg} / \mathrm{m}^{2}\right)$, mean (SE) & $27.3(0.1)$ & $29.6(0.2)$ & $31.5(0.4)$ & $<0.001$ \\
\hline \multicolumn{5}{|l|}{ Month of blood collection, n (\%) } \\
\hline 1 November to 30 April (winter) & $2,688(34.4)$ & $1,980(50.7)$ & 999 (57.6) & \multirow[t]{2}{*}{$<0.001$} \\
\hline 1 May to 31 October (summer) & $4,274(65.6)$ & $1,640(49.3)$ & $676(42.4)$ & \\
\hline \multicolumn{5}{|l|}{ Education, n (\%) } \\
\hline Less than high school & $1,694(14.8)$ & $1,194(21.8)$ & $621(28.5)$ & \multirow[t]{3}{*}{$<0.001$} \\
\hline High school & $1,729(25.3)$ & $872(26.3)$ & $384(25.4)$ & \\
\hline Greater than high school & $3,535(59.9)$ & $1,550(51.9)$ & $667(46.1)$ & \\
\hline \multicolumn{5}{|l|}{ Race/ethnicity, n (\%) } \\
\hline Non-Hispanic Caucasian & $4,812(84.5)$ & $1,390(59.5)$ & $316(33.9)$ & \multirow[t]{4}{*}{$<0.001$} \\
\hline Non-Hispanic Black & $558(3.5)$ & $965(17.0)$ & $906(44.8)$ & \\
\hline Hispanic & 1,394 (8.6) & $1,091(16.5)$ & $394(14.1)$ & \\
\hline Others & $198(3.4)$ & $174(7.1)$ & $59(7.1)$ & \\
\hline \multicolumn{5}{|l|}{ Family poverty income ratio, $\mathrm{n}(\%)$} \\
\hline$<1$ & $929(9.7)$ & $661(15.6)$ & $358(20.0)$ & \multirow[t]{3}{*}{$<0.001$} \\
\hline 1 to 4 & $4,181(61.5)$ & $2,230(63.6)$ & $1,031(65.7)$ & \\
\hline$\geq 5$ & $1,507(28.8)$ & $516(20.8)$ & $181(14.3)$ & \\
\hline \multicolumn{5}{|l|}{ Smoker, n (\%) } \\
\hline Non-smoker & $3,407(49.5)$ & $1,856(50.0)$ & $869(50.0)$ & \multirow[t]{3}{*}{$<0.001$} \\
\hline Former smoker & $1,914(24.8)$ & $833(21.0)$ & $303(16.3)$ & \\
\hline Current smoker & $1,637(25.7)$ & $926(29.0)$ & $500(33.8)$ & \\
\hline \multicolumn{5}{|l|}{ Alcohol user, n (\%) } \\
\hline Non-drinker & $784(15.0)$ & $555(21.5)$ & $293(24.2)$ & \multirow[t]{3}{*}{$<0.001$} \\
\hline Former drinker & $559(10.3)$ & $382(14.3)$ & $187(14.1)$ & \\
\hline Current drinker & $3,139(74.8)$ & $1,452(64.2)$ & $639(61.7)$ & \\
\hline \multicolumn{5}{|l|}{ Physical activity during the day, n (\%) } \\
\hline Sit and not walk about very much & $1,512(21.2)$ & $960(27.0)$ & $541(32.9)$ & \multirow[t]{4}{*}{$<0.001$} \\
\hline Walk a lot & $3,584(50.4)$ & $1,904(50.5)$ & $857(49.2)$ & \\
\hline Light work & $1,276(20.5)$ & $497(15.2)$ & $202(13.9)$ & \\
\hline Heavy work & $582(8.0)$ & $254(7.3)$ & $73(4.0)$ & \\
\hline $\begin{array}{l}\text { Leisure time physical activity } \\
\text { (Metabolic equivalent/h/week), mean (SE) }\end{array}$ & $1,292.4(52.2)$ & $788.5(55.6)$ & $674.2(53.1)$ & $<0.001$ \\
\hline Users of supplement containing vitamin D (\%) & $3,258(47.2)$ & $1,018(30.4)$ & $202(12.5)$ & $<0.001$ \\
\hline Users of supplement containing Ca (\%) & $3,860(57.1)$ & $1,380(42.6)$ & $351(22.3)$ & $<0.001$ \\
\hline Users of supplement containing Mg (\%) & $3,040(45.1)$ & $1,072(32.0)$ & $235(14.9)$ & $<0.001$ \\
\hline \multicolumn{5}{|l|}{ Energy-adjusted nutrient intakes ${ }^{c}$, mean (SE) } \\
\hline Protein (g/day) & $82.0(0.5)$ & $80.1(0.7)$ & $77.8(1.3)$ & $<0.01$ \\
\hline Carbohydrate (g/day) & $258.5(1.4)$ & $262.4(1.7)$ & $261.6(2.9)$ & 0.135 \\
\hline Fat (g/day) & $80.7(0.5)$ & $80.3(0.6)$ & $81.2(0.9)$ & 0.93 \\
\hline Calcium (mg/day) & $929.0(8.4)$ & $805.2(9.1)$ & $690.3(13.6)$ & $<0.001$ \\
\hline Magnesium (mg/day) & $293.1(2.2)$ & $266.6(2.9)$ & $252.4(4.2)$ & $<0.001$ \\
\hline
\end{tabular}


Table 1 Selected characteristics of the study participants by serum 25(OH)D levels, National Health and Nutrition Examination Survey (NHANES) 2001 to 2006 (Continued)

\begin{tabular}{|c|c|c|c|c|}
\hline Vitamin D (IU/day) & $196(8.0)$ & $160(8.0)$ & $116(8.0)$ & $<0.001$ \\
\hline Total calcium (mg/day) $)^{d}$ & 1,168.8 (12.6) & $935.4(12.3)$ & 748.5 (15.9) & $<0.001$ \\
\hline Total magnesium $(\mathrm{mg} / \text { day })^{d}$ & $344.2(3.5)$ & $297.3(3.2)$ & $262.4(4.4)$ & $<0.001$ \\
\hline Total vitamin D (IU/day) ${ }^{d}$ & $376(8.0)$ & $276(8.0)$ & $152(8.0)$ & $<0.001$ \\
\hline
\end{tabular}

${ }^{a}$ Values are present as weighted means (SE) and unweighted frequencies (weighted percentages, \%).

${ }^{b}$ Rao-Scott $X^{2}$ test for categorical data and analysis of variance (ANOVA) test for continuous variables.

'Values are energy-adjusted means (SE).

${ }^{\mathrm{d}}$ Total calcium, magnesium and vitamin D intake from foods and supplements.

stratified analysis $\left(P_{\text {interaction }}, 0.15\right)$ was very similar to that for total mortality and mortality due to CVD.

\section{Discussion}

Consistent with our hypothesis, we observed that high intake of total, dietary or supplemental magnesium was independently and significantly associated with reduced risks of both vitamin D deficiency and insufficiency. Furthermore, intake of magnesium significantly interacted with intakes of vitamin $\mathrm{D}$ in relation to both vitamin $\mathrm{D}$ deficiency and insufficiency. In the NHANES III cohort, a population-based prospective study, we found the inverse associations of serum $25(\mathrm{OH}) \mathrm{D}$ with mortality, particularly mortality due to CVD and colorectal cancer, were modified by magnesium intake, and the inverse associations were primarily present among those with magnesium intake above the median. In addition, we found the inverse association between magnesium intake and risk of vitamin D deficiency primarily occurred in those who had the highest or the lowest tertile of PTH level; while the inverse association between total magnesium intake and vitamin D insufficiency primarily appeared among populations at high risk of vitamin $\mathrm{D}$ insufficiency. To the best of our knowledge, this is the first study to examine the interaction between vitamin $\mathrm{D}$ and magnesium in association to mortality; and this is the first study to suggest a potential independent contribution of total magnesium intake and its interaction with vitamin D intake to vitamin D status in the general population.

Under normal physiologic conditions, $25(\mathrm{OH}) \mathrm{D}$ is derived primarily from endogenous synthesis via exposure of skin to sunlight because few natural foods contain vitamin $\mathrm{D}$ except by fortification or supplementation (see Figure 1). Vitamin $D_{3}$ or $D_{2}$ is transferred to the liver via vitamin $\mathrm{D}$ binding protein (VDBP) and converted to $25(\mathrm{OH}) \mathrm{D}$ by 25 -hydroxylase and subsequently carried to the kidney by VDBP and converted to $1,25(\mathrm{OH})_{2} \mathrm{D}$ by $1 \alpha$-hydroxylase enzyme. Both $25(\mathrm{OH}) \mathrm{D}$ and $1,25(\mathrm{OH})_{2} \mathrm{D}$ can be converted by 24-hydroxylase to the $24,25(\mathrm{OH})_{2} \mathrm{D}$ or $1,24,25(\mathrm{OH})_{3} \mathrm{D}$, respectively [37]. Therefore, $25(\mathrm{OH}) \mathrm{D}$ levels are primarily determined by VDBP, 25-hydroxylase, $1 \alpha$-hydroxylase and 24-hydroxy- lase activity, a fact that has recently been substantiated by a genome-wide association study [38]. Based on previous in vitro studies, magnesium status regulates both $1 \alpha$-hydroxylase and 24-hydroxylase activity [22,24]. Previous studies indicated both VDBP [23] and 25hydroxylase [25,39] might also be magnesium dependent. Therefore, magnesium would be expected to play an important role in $25(\mathrm{OH}) \mathrm{D}$ metabolism.

A previous clinical study found that parenteral magnesium treatment without vitamin D replacement in 23 magnesium-deficient patients led to a $12 \%$ rise in 25 $(\mathrm{OH}) \mathrm{D}$ and $30 \%$ increase in $1,25(\mathrm{OH})_{2} \mathrm{D}$, but both changes were not statistically significant [23]. In a subsequent study of five magnesium-deficient patients, intramuscular treatment with magnesium alone also did not significantly increase $25(\mathrm{OH}) \mathrm{D}$, but magnesium infusion together with pharmacological dose of $25(\mathrm{OH}) \mathrm{D}$ substantially increased both $25(\mathrm{OH}) \mathrm{D}$ and $1,25(\mathrm{OH})_{2} \mathrm{D}$ among patients with magnesium deficiency. One interpretation is that magnesium treatment does not affect $25(\mathrm{OH}) \mathrm{D}$ status [23,27]. However, we postulate that several factors may have contributed to the insignificant increase in $25(\mathrm{OH}) \mathrm{D}$ status. First, the subjects participating in these studies had low concentrations of $25(\mathrm{OH}) \mathrm{D}$ and $1,25(\mathrm{OH})_{2} \mathrm{D}$ as well as pre-vitamin $\mathrm{D}_{3}$ and vitamin $\mathrm{D}_{3}$ as a result of limited sunlight exposure, underlying disease and/or lack of oral supplementation. Therefore, concentrations of $25(\mathrm{OH}) \mathrm{D}$ and $1,25(\mathrm{OH})_{2} \mathrm{D}$ did not substantially increase during short-term magnesium repletion because pre-vitamin D3 was not available in sufficient amounts. Second, there was a modest increase in the conversion of $25(\mathrm{OH}) \mathrm{D}$ to $1,25(\mathrm{OH})_{2} \mathrm{D}$ and, thus, a reduction in $25(\mathrm{OH})$ D level was expected due to this conversion [22]. Finally, the sample size in these two studies was very small particularly if the direct effect of magnesium treatment on vitamin $\mathrm{D}$ status is only moderate.

We found that high magnesium intake was also associated with a reduced risk of vitamin D deficiency or insufficiency. We believe that this observation is the result of the interaction between various metabolic pathways that regulate $25(\mathrm{OH}) \mathrm{D}$ levels. Previous studies have shown that endogenously synthesized vitamin $D_{3}$ is transferred almost completely by VDBP to liver and this 
Table 2 Multivariate-adjusted odds ratios $(95 \% \mathrm{Cls})^{\mathrm{a}}$ for associations between total intakes of vitamin $\mathrm{D}$ and magnesium and risk of vitamin D deficiency and insufficiency, National Health and Nutrition Examination Survey (NHANES) 2001 to 2006

\begin{tabular}{|c|c|c|c|c|c|}
\hline \multirow[t]{2}{*}{ Nutrient intakes } & \multirow{2}{*}{$\begin{array}{l}\text { Controls, } \\
\mathrm{N}\end{array}$} & \multicolumn{2}{|c|}{ Deficiency } & \multicolumn{2}{|c|}{ Insufficiency } \\
\hline & & $\mathbf{N}$ & OR $(95 \% \mathrm{CI})$ & $\mathbf{N}$ & OR $(95 \% \mathrm{CI})$ \\
\hline \multicolumn{6}{|c|}{ Total vitamin D intake (IU/day) } \\
\hline Q1 <114 & 1,741 & 1,005 & 1.00 & 1,450 & 1.00 \\
\hline Q2 114 to 307 & 1,740 & 446 & 0.55 (0.40 to 0.75$)$ & 1,086 & $0.75(0.62$ to 0.91$)$ \\
\hline Q3 308 to 539 & 1,741 & 152 & $0.22(0.15$ to 0.34$)$ & 665 & 0.55 (0.44 to 0.69$)$ \\
\hline Q4 $\geq 540$ & 1,740 & 72 & $0.10(0.06$ to 0.17$)$ & 419 & $0.37(0.27$ to 0.51$)$ \\
\hline$P$ for trend & & & $<0.001$ & & $<0.001$ \\
\hline \multicolumn{6}{|c|}{ Dietary vitamin D intake (IU/day) } \\
\hline Q1 $<57.8$ & 1,741 & 764 & 1.00 & 1,183 & 1.00 \\
\hline Q2 57.8 to 137 & 1,740 & 468 & 0.71 (0.55 to 0.91$)$ & 997 & 0.86 (0.71 to 1.05$)$ \\
\hline Q3 138 to 261 & 1,741 & 279 & 0.54 (0.40 to 0.72$)$ & 807 & 0.72 (0.59 to 0.88$)$ \\
\hline Q4 $\geq 262$ & 1,740 & 164 & $0.29(0.20$ to 0.41$)$ & 633 & 0.69 (0.56 to 0.86$)$ \\
\hline$P$ for trend & & & $<0.001$ & & $<0.001$ \\
\hline \multicolumn{6}{|c|}{ Supplemental vitamin D intake (IU/day) } \\
\hline Non-user & 3,704 & 1,473 & 1.00 & 2,602 & 1.00 \\
\hline 1 to 239 & 809 & 93 & $0.32(0.20$ to 0.50$)$ & 377 & 0.84 (0.68 to 1.03$)$ \\
\hline 240 to 399 & 331 & 19 & 0.29 (0.13 to 0.64$)$ & 109 & 0.57 (0.38 to 0.87$)$ \\
\hline$\geq 400$ & 2,118 & 90 & 0.19 (0.11 to 0.33$)$ & 532 & $0.40(0.29$ to 0.53$)$ \\
\hline$P$ for trend & & & $<0.001$ & & $<0.001$ \\
\hline \multicolumn{6}{|c|}{ Total magnesium intake (mg/day) } \\
\hline Q1 $<225$ & 1,749 & 876 & 1.00 & 1,362 & 1.00 \\
\hline Q2 225 to 310 & 1,733 & 392 & $0.67(0.50$ to 0.90$)$ & 907 & $0.78(0.61$ to 1.00$)$ \\
\hline Q3 311 to 419 & 1,737 & 245 & $0.43(0.30$ to 0.63$)$ & 758 & 0.73 (0.59 to 0.89$)$ \\
\hline Q4 $\geq 420$ & 1,743 & 162 & $0.34(0.21$ to 0.56$)$ & 593 & $0.62(0.46$ to 0.82$)$ \\
\hline$P$ for trend & & & $<0.001$ & & $<0.001$ \\
\hline \multicolumn{6}{|c|}{ Dietary magnesium intake (mg/day) } \\
\hline Q1 <195 & 1,754 & 726 & 1.00 & 1,255 & 1.00 \\
\hline Q2 195 to 268 & 1,732 & 432 & 0.75 (0.58 to 0.97$)$ & 893 & $0.75(0.62$ to 0.90$)$ \\
\hline Q3 269 to 363 & 1,741 & 297 & 0.68 (0.47 to 0.99$)$ & 777 & 0.69 (0.55 to 0.87$)$ \\
\hline Q4 $\geq 364$ & 1,735 & 220 & $0.43(0.26$ to 0.70$)$ & 695 & $0.61(0.45$ to 0.83$)$ \\
\hline$P$ for trend & & & 0.002 & & 0.002 \\
\hline \multicolumn{6}{|c|}{ Supplemental magnesium intake (mg/day) } \\
\hline Non-user & 3,922 & 1,440 & 1.00 & 2,548 & 1.00 \\
\hline 1 to 49 & 669 & 109 & $0.53(0.34$ to 0.81$)$ & 334 & $1.14(0.91$ to 1.43$)$ \\
\hline 50 to 99 & 506 & 43 & 0.35 (0.17 to 0.71$)$ & 205 & $0.80(0.53$ to 1.22$)$ \\
\hline$\geq 100$ & 1,865 & 83 & $0.30(0.17$ to 0.52$)$ & 533 & 0.68 (0.52 to 0.88$)$ \\
\hline$P$ for trend & & & $<0.001$ & & 0.008 \\
\hline
\end{tabular}

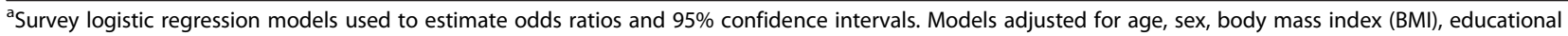
attainment, race, household income, smoking status, alcohol use, physical activity, month of blood collection, dietary intakes of total energy and total calcium intake. Models were also adjusted for total intake of vitamin D or magnesium mutually. 
Table 3 Odds ratios $(95 \% \mathrm{Cl})^{\mathrm{a}}$ for vitamin $\mathrm{D}$ deficiency and insufficiency stratified by the median of vitamin $\mathrm{D}$ intake or season, National Health and Nutrition Examination Survey (NHANES) 2001 to 2006

\begin{tabular}{|c|c|c|c|c|c|}
\hline \multirow[t]{2}{*}{ Magnesium intake, mg/day } & \multirow{2}{*}{$\begin{array}{l}\text { Controls, } \\
\mathrm{N}\end{array}$} & \multicolumn{2}{|c|}{ Deficiency } & \multicolumn{2}{|c|}{ Insufficiency } \\
\hline & & $\mathbf{N}$ & OR $(95 \% \mathrm{Cl})$ & $\mathbf{N}$ & OR $(95 \% \mathrm{Cl})$ \\
\hline \multicolumn{6}{|c|}{ Vitamin D intake <308 (IU/day) } \\
\hline Q1 $<225$ & 1,359 & 834 & 1.00 & 1,218 & 1.00 \\
\hline Q2 225 to 310 & 940 & 328 & 0.79 (0.58 to 1.07$)$ & 650 & 0.89 (0.69 to 1.15$)$ \\
\hline Q3 311 to 419 & 697 & 184 & 0.64 (0.46 to 0.91$)$ & 426 & 0.78 (0.63 to 1.08 ) \\
\hline Q4 $\geq 420$ & 485 & 105 & 0.58 (0.35 to 0.97$)$ & 242 & 0.71 (0.47 to 1.07 ) \\
\hline$P$ for trend & & & 0.01 & & $<0.05$ \\
\hline \multicolumn{6}{|c|}{ Vitamin D intake $\geq 308$ (IU/day) } \\
\hline Q1 $<225$ & 390 & 42 & 1.00 & 144 & 1.00 \\
\hline Q2 225 to 310 & 793 & 64 & 1.09 (0.47 to 2.55$)$ & 257 & 0.94 (0.62 to 1.42$)$ \\
\hline Q3 311 to 419 & 1,040 & 61 & 0.76 (0.30 to 1.88$)$ & 332 & 1.19 (0.80 to 1.77$)$ \\
\hline Q4 $\geq 420$ & 1,258 & 57 & $0.71(0.24$ to 2.11$)$ & 351 & 0.96 (0.60 to 1.55$)$ \\
\hline$P$ for trend & & & 0.97 & & 0.67 \\
\hline$P$ for interaction & & & $<0.001$ & & $<0.001$ \\
\hline \multicolumn{6}{|c|}{ Non-vitamin D supplement user } \\
\hline Q1 $<225$ & 1,292 & 812 & 1.00 & 1,160 & 1.00 \\
\hline Q2 225 to 310 & 958 & 332 & $0.81(0.57$ to 1.14$)$ & 651 & 0.91 (0.70 to 1.18 ) \\
\hline Q3 311 to 419 & 793 & 205 & 0.59 (0.40 to 0.88$)$ & 462 & 0.80 (0.63 to 1.02$)$ \\
\hline Q4 $\geq 420$ & 661 & 124 & $0.60(0.35$ to 1.00$)$ & 329 & 0.81 (0.55 to 1.19 ) \\
\hline$P$ for trend & & & 0.02 & & 0.18 \\
\hline \multicolumn{6}{|c|}{ Vitamin D supplement user } \\
\hline Q1 $<225$ & 457 & 64 & 1.00 & 202 & 1.00 \\
\hline Q2 225 to 310 & 775 & 60 & 1.23 (0.59 to 2.56$)$ & 256 & 0.80 (0.53 to 1.20$)$ \\
\hline Q3 311 to 419 & 944 & 40 & 1.05 (0.41 to 1.68$)$ & 296 & 0.96 (0.65 to 1.41$)$ \\
\hline $\mathrm{Q} 4 \geq 420$ & 1,082 & 38 & $0.91(0.35$ to 2.36$)$ & 264 & 0.73 (0.49 to 1.10$)$ \\
\hline$P$ for trend & & & 0.56 & & 0.40 \\
\hline$P$ for interaction & & & 0.47 & & 0.37 \\
\hline \multicolumn{6}{|c|}{ Winter and Southern latitude } \\
\hline Q1 $<225$ & 664 & 493 & 1.00 & 726 & 1.00 \\
\hline Q2 225 to 310 & 691 & 239 & 0.63 (0.47 to 0.85$)$ & 495 & 0.73 (0.57 to 0.92 ) \\
\hline Q3 311 to 419 & 653 & 156 & 0.49 (0.30 to 0.78$)$ & 422 & 0.89 (0.74 to 1.07$)$ \\
\hline Q4 $\geq 420$ & 680 & 111 & 0.54 (0.28 to 1.02$)$ & 337 & 0.57 (0.41 to 0.78 ) \\
\hline$P$ for trend & & & 0.03 & & $<0.01$ \\
\hline \multicolumn{6}{|c|}{ Summer and Northern latitude } \\
\hline Q1 $<225$ & 1,085 & 383 & 1.00 & 636 & 1.00 \\
\hline Q2 225 to 310 & 1,042 & 153 & 0.95 (0.64 to 1.41$)$ & 412 & 0.91 (0.66 to 1.26$)$ \\
\hline Q3 311 to 419 & 1,084 & 89 & 0.61 (0.43 to 0.86$)$ & 336 & 0.73 (0.56 to 0.96$)$ \\
\hline $\mathrm{Q} 4 \geq 420$ & 1,063 & 51 & 0.33 (0.20 to 0.55$)$ & 256 & 0.85 (0.61 to 1.19$)$ \\
\hline$P$ for trend & & & 0.001 & & 0.35 \\
\hline$P$ for interaction & & & 0.55 & & 0.21 \\
\hline \multicolumn{6}{|c|}{ Age <50 (years) } \\
\hline Q1 $<225$ & 862 & 465 & 1.00 & 726 & 1.00 \\
\hline Q2 225 to 310 & 821 & 209 & 0.74 (0.49 to 1.11$)$ & 495 & 0.83 (0.60 to 1.16$)$ \\
\hline
\end{tabular}


Table 3 Odds ratios $(95 \% \mathrm{Cl})^{a}$ for vitamin $\mathrm{D}$ deficiency and insufficiency stratified by the median of vitamin $\mathrm{D}$ intake or season, National Health and Nutrition Examination Survey (NHANES) 2001 to 2006 (Continued)

\begin{tabular}{|c|c|c|c|c|c|}
\hline Q3 311 to 419 & 831 & 150 & 0.63 (0.35 to 1.13$)$ & 422 & 0.84 (0.62 to 1.13 ) \\
\hline Q4 $\geq 420$ & 892 & 110 & 0.67 (0.32 to 1.42$)$ & 337 & 0.73 (0.50 to 1.08 ) \\
\hline$P$ for trend & & & 0.26 & & 0.15 \\
\hline \multicolumn{6}{|c|}{ Age $\geq 50$ (years) } \\
\hline Q1 $<225$ & 1,085 & 383 & 1.00 & 636 & 1.00 \\
\hline Q2 225 to 310 & 1,042 & 153 & 0.85 (0.50 to 1.37$)$ & 412 & 0.86 (0.63 to 1.16$)$ \\
\hline Q3 311 to 419 & 1,084 & 89 & 0.43 (0.24 to 0.77$)$ & 336 & 0.79 (0.57 to 1.10$)$ \\
\hline $\mathrm{Q} 4 \geq 420$ & 1,063 & 51 & 0.24 (0.11 to 0.49$)$ & 256 & 0.71 (0.46 to 1.10 ) \\
\hline$P$ for trend & & & $<0.01$ & & 0.81 \\
\hline$P$ for interaction & & & 0.07 & & 0.41 \\
\hline \multicolumn{6}{|c|}{ Male } \\
\hline Q1 $<225$ & 712 & 283 & 1.00 & 519 & 1.00 \\
\hline Q2 225 to 310 & 854 & 164 & 0.64 (0.41 to 1.00$)$ & 466 & 1.12 (0.78 to 1.61$)$ \\
\hline Q3 311 to 419 & 995 & 143 & 0.39 (0.21 to 0.74$)$ & 439 & 0.90 (0.65 to 1.26$)$ \\
\hline $\mathrm{Q} 4 \geq 420$ & 1,150 & 106 & 0.33 (0.16 to 0.69$)$ & 409 & 0.95 (0.59 to 1.52 ) \\
\hline$P$ for trend & & & 0.001 & & 0.54 \\
\hline \multicolumn{6}{|c|}{ Female } \\
\hline Q1 $<225$ & 1,037 & 593 & 1.00 & 843 & 1.00 \\
\hline Q2 225 to 310 & 879 & 228 & 0.85 (0.61 to 1.21$)$ & 441 & 0.71 (0.54 to 0.93 ) \\
\hline Q3 311 to 419 & 742 & 102 & 0.63 (0.37 to 1.05$)$ & 319 & 0.83 (0.64 to 1.07 ) \\
\hline Q4 $\geq 420$ & 593 & 56 & 0.47 (0.25 to 0.87$)$ & 184 & 0.60 (0.43 to 0.82 ) \\
\hline$P$ for trend & & & 0.16 & & 0.14 \\
\hline$P$ for interaction & & & 0.11 & & 0.17 \\
\hline \multicolumn{6}{|c|}{ Non-Hispanic Black } \\
\hline Q1 $<225$ & 181 & 530 & 1.00 & 442 & 1.00 \\
\hline Q2 225 to 310 & 163 & 181 & 0.51 (0.34 to 0.76$)$ & 229 & 0.74 (0.53 to 1.03$)$ \\
\hline Q3 311 to 419 & 110 & 115 & 0.44 (0.26 to 0.74$)$ & 175 & 0.53 (0.33 to 0.88 ) \\
\hline Q4 $\geq 420$ & 104 & 81 & $0.43(0.27$ to 0.68$)$ & 119 & 0.64 (0.39 to 1.04$)$ \\
\hline$P$ for trend & & & $<0.001$ & & $<0.05$ \\
\hline \multicolumn{6}{|c|}{ Non-Hispanic Caucasian and others } \\
\hline Q1 $<225$ & 1,568 & 346 & 1.00 & 920 & 1.00 \\
\hline Q2 225 to 310 & 1,570 & 212 & 0.91 (0.65 to 1.28$)$ & 678 & 0.86 (0.67 to 1.10$)$ \\
\hline Q3 311 to 419 & 1,627 & 130 & 0.66 (0.45 to 0.97$)$ & 583 & 0.87 (0.67 to 1.10$)$ \\
\hline Q4 $\geq 420$ & 1,639 & 81 & 0.52 (0.29 to 0.95$)$ & 474 & 0.76 (0.58 to 0.99$)$ \\
\hline$P$ for trend & & & $<0.05$ & & 0.27 \\
\hline$P$ for interaction & & & 0.305 & & 0.82 \\
\hline \multicolumn{6}{|c|}{$\mathrm{BMI}<25\left(\mathrm{~kg} / \mathrm{m}^{2}\right)$} \\
\hline Q1 $<225$ & 631 & 172 & 1.00 & 336 & 1.00 \\
\hline Q2 225 to 310 & 611 & 90 & 1.04 (0.51 to 2.12$)$ & 339 & 0.92 (0.61 to 1.40 ) \\
\hline Q3 311 to 419 & 606 & 58 & 0.84 (0.40 to 1.76$)$ & 189 & 1.00 (0.70 to 1.44$)$ \\
\hline $\mathrm{Q} 4 \geq 420$ & 608 & 41 & 0.51 (0.23 to 1.15$)$ & 162 & 0.77 (0.47 to 1.27 ) \\
\hline$P$ for trend & & & 0.13 & & 0.45 \\
\hline \multicolumn{6}{|c|}{$\mathrm{BMI} \geq 25$ to $<30\left(\mathrm{~kg} / \mathrm{m}^{2}\right)$} \\
\hline Q1 $<225$ & 605 & 232 & 1.00 & 448 & 1.00 \\
\hline
\end{tabular}


Table 3 Odds ratios $(95 \% \mathrm{Cl})^{\mathrm{a}}$ for vitamin $\mathrm{D}$ deficiency and insufficiency stratified by the median of vitamin $\mathrm{D}$ intake or season, National Health and Nutrition Examination Survey (NHANES) 2001 to 2006 (Continued)

\begin{tabular}{|c|c|c|c|c|c|}
\hline Q2 225 to 310 & 632 & 106 & 0.71 (0.43 to 1.15$)$ & 316 & 0.77 (0.51 to 1.17$)$ \\
\hline Q3 311 to 419 & 661 & 75 & 0.50 (0.29 to 0.86$)$ & 266 & 0.63 (0.50 to 0.79$)$ \\
\hline Q4 $\geq 420$ & 677 & 46 & $0.47(0.22$ to 1.01$)$ & 213 & 0.73 (0.48 to 1.13$)$ \\
\hline$P$ for trend & & & 0.02 & & 0.06 \\
\hline \multicolumn{6}{|c|}{$\mathrm{BMI} \geq 30\left(\mathrm{~kg} / \mathrm{m}^{2}\right)$} \\
\hline Q1 $<225$ & 463 & 440 & 1.00 & 532 & 1.00 \\
\hline Q2 225 to 310 & 457 & 177 & 0.63 (0.35 to 1.14$)$ & 341 & 0.82 (0.63 to 1.06$)$ \\
\hline Q3 311 to 419 & 441 & 108 & 0.46 (0.24 to 0.88$)$ & 288 & 0.83 (0.59 to 1.15$)$ \\
\hline $\mathrm{Q} 4 \geq 420$ & 424 & 69 & 0.42 (0.19 to 0.96$)$ & 202 & 0.63 (0.44 to 0.91$)$ \\
\hline$P$ for trend & & & 0.02 & & 0.02 \\
\hline$P$ for interaction & & & 0.23 & & 0.13 \\
\hline \multicolumn{6}{|c|}{$\mathrm{PTH}<32(\mathrm{pg} / \mathrm{ml})$} \\
\hline Q1 $<225$ & 322 & 63 & 1.00 & 179 & 1.00 \\
\hline Q2 225 to 310 & 369 & 39 & 0.42 (0.18 to 1.02$)$ & 109 & $0.72(0.42$ to 1.24$)$ \\
\hline Q3 311 to 419 & 363 & 21 & 0.17 (0.07 to 0.43$)$ & 107 & 0.77 (0.47 to 1.28$)$ \\
\hline Q4 $\geq 420$ & 392 & 19 & 0.22 (0.07 to 0.73$)$ & 100 & 0.74 (0.38 to 1.42$)$ \\
\hline$P$ for trend & & & $<0.01$ & & 0.46 \\
\hline \multicolumn{6}{|c|}{ PTH $\geq 32$ to $<46(\mathrm{pg} / \mathrm{ml})$} \\
\hline Q1 $<225$ & 378 & 136 & 1.00 & 271 & 1.00 \\
\hline Q2 225 to 310 & 382 & 66 & 1.20 (0.66 to 2.21$)$ & 195 & 0.94 (0.73 to 1.22$)$ \\
\hline Q3 311 to 419 & 406 & 54 & 1.19 (0.53 to 2.66$)$ & 181 & 0.85 (0.59 to 1.23$)$ \\
\hline $\mathrm{Q} 4 \geq 420$ & 414 & 33 & 1.11 (0.36 to 3.42 ) & 131 & 0.79 (0.55 to 1.15$)$ \\
\hline$P$ for trend & & & 0.85 & & 0.24 \\
\hline \multicolumn{6}{|c|}{ PTH $\geq 46(\mathrm{pg} / \mathrm{ml})$} \\
\hline Q1 $<225$ & 390 & 375 & 1.00 & 447 & 1.00 \\
\hline Q2 225 to 310 & 382 & 157 & 0.73 (0.48 to 1.10$)$ & 297 & 0.93 (0.68 to 1.28$)$ \\
\hline Q3 311 to 419 & 382 & 95 & 0.52 (0.28 to 0.95$)$ & 209 & 0.78 (0.60 to 1.01$)$ \\
\hline $\mathrm{Q} 4 \geq 420$ & 365 & 50 & 0.28 (0.14 to 0.53$)$ & 159 & 0.57 (0.35 to 0.92$)$ \\
\hline$P$ for trend & & & 0.01 & & 0.41 \\
\hline$P$ for interaction & & & 0.73 & & 0.53 \\
\hline
\end{tabular}

Parathyroid hormone (PTH) laboratory results were only available from the NHANES 2003 to 2006.

a Survey logistic regression models used to estimate odds ratios and 95\% confidence intervals. Models were adjusted for age, sex, body mass index (BMI),

educational attainment, race, household income, smoking status, alcohol use, physical activity, month of blood collection, dietary intakes of total energy, total intake of calcium and vitamin D.

transport is slow, leading to a more sustained plasma vitamin $D_{3}$, compared to that from supplementation of vitamin $\mathrm{D}$, which is delivered to the liver by non-VDBP carriers in the plasma [40]. VDBP may also be an important determinant of serum $25(\mathrm{OH}) \mathrm{D}$ concentration, particularly when dietary intake of vitamin $\mathrm{D}$ is low. In the study by Rude et al., the concentration of VDBP was lower among 11 magnesium-deficient patients and significantly increased to normal after magnesium treatment without vitamin D supplementation [23]. Therefore, it is possible that an improvement in magnesium status leads to an increase in VDBP synthesis and, in turn, an elevated transport of vitamin $\mathrm{D}_{3}$ to the liver and $25(\mathrm{OH}) \mathrm{D}$ to the kidney.

The critical roles of magnesium in the synthesis of VDBP, PTH, $25(\mathrm{OH}) \mathrm{D}$ and $1,25(\mathrm{OH})_{2} \mathrm{D}$ may partially explain why the inverse associations between serum 25 $(\mathrm{OH}) \mathrm{D}$ and risk of total mortality and mortality due to colorectal cancer and CVD primarily existed among those with magnesium intake above the median. High magnesium may increase the availability of $1,25(\mathrm{OH}) 2 \mathrm{D}$ through activating the synthesis of $25(\mathrm{OH}) \mathrm{D}$ and 1,25 $(\mathrm{OH}) 2 \mathrm{D}$ and increasing the transfer to target tissues by elevating vitamin $\mathrm{D}$ binding protein (VDBP) (Figure 1). 
Table 4 Hazard ratios $(\mathrm{HRs})^{\mathrm{a}}$ and $95 \%$ Cls for total mortality in the National Health and Nutrition Examination Survey (NHANES) III (1988 to 2006)

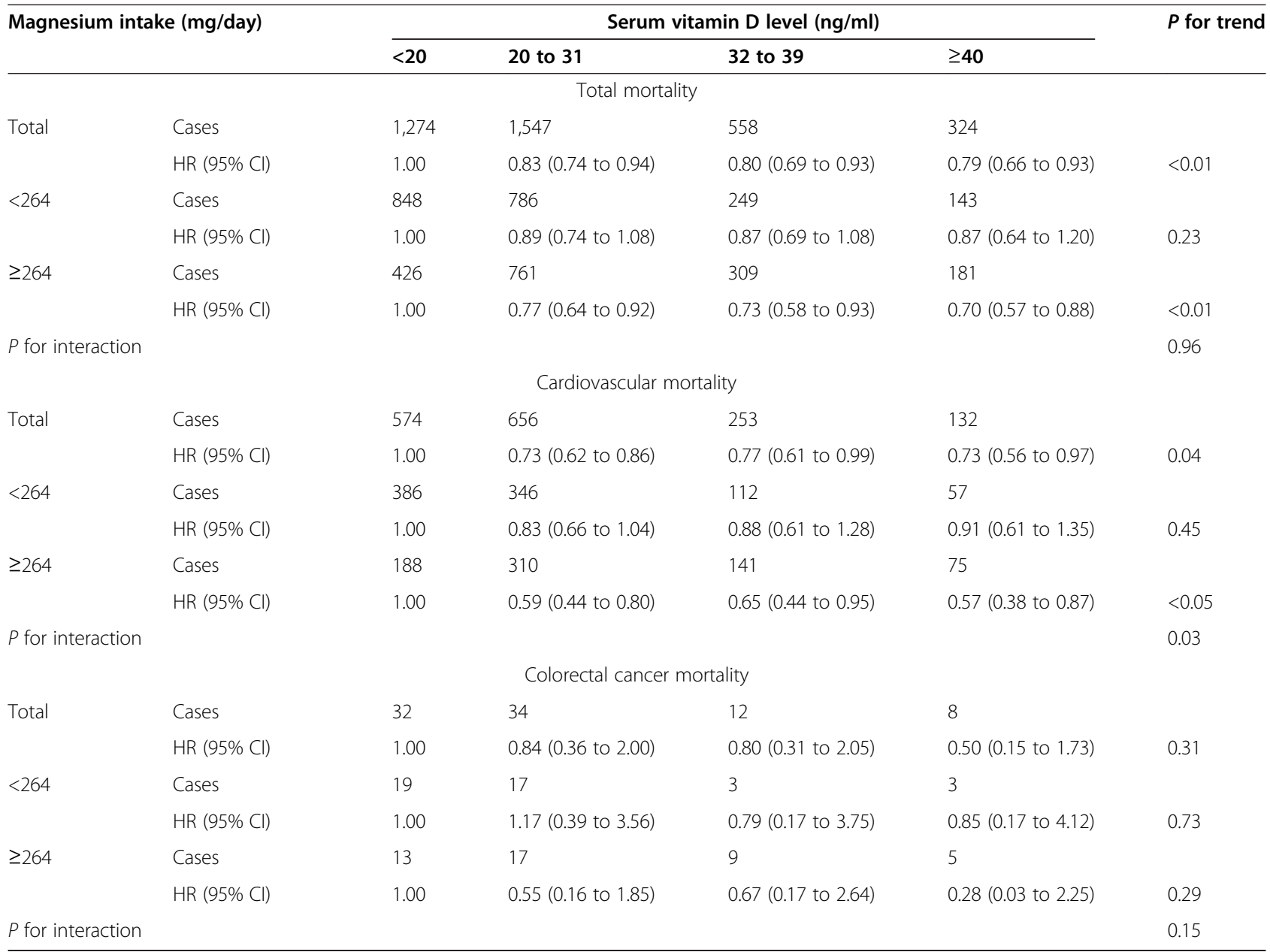

${ }^{\mathrm{a} A}$ Cox's proportional hazards model was performed with the SURVEYPHREG procedure to estimate odds ratios and $95 \%$ confidence intervals. Models were adjusted for age, race, sex, BMI, education attainment, household income, smoking status, alcohol use, physical activity, month of blood collection, intakes of total energy, phosphorus, calcium and magnesium.

This explanation is also supported by the observation in previous clinical studies that magnesium supplementation substantially reversed the resistance to vitamin D treatment among magnesium-deficient patients [21].

Previous studies found PTH level was elevated when serum 25(OH)D was under $20 \mathrm{ng} / \mathrm{ml}$ [41]. In the current study, we found magnesium intake was associated with a reduced risk of vitamin D insufficiency or deficiency only among those in the highest or the lowest tertile of PTH. This finding is possible because magnesium plays an important role in PTH regulation. This finding is also supported by observations made in a study of 30 women with osteoporosis that were investigated for magnesium deficiency using a magnesium tolerance test [26]. The subjects were divided into three groups: ten with vitamin $\mathrm{D}$ insufficiency (low vitamin D and raised PTH); ten with functional hypoparathyroidism (low vitamin D and low/low normal PTH); and ten who were vitamin D replete (normal vitamin D and normal PTH). All ten subjects with functional hypoparathyroidism were found to be magnesium deficient; five magnesium-deficient and five magnesium-insufficient patients were found in the subjects with vitamin D insufficiency, and only one magnesium-deficient and four magnesium-insufficient patients were found in the vitamin D replete group. Furthermore, intravenous magnesium infusion led to a significant rise in PTH in the group with functional hypoparathyroidism and a reduction in PTH in the subjects with vitamin D insufficiency.

A number of previous studies have examined the associations between magnesium intake with risk of stroke $[42,43]$ and coronary heart disease $[43,44]$, however, the results have been inconsistent in these previous studies. Two meta-analyses of prospective studies found that magnesium intake was related to a significantly reduced risk of stroke $[42,43]$. However, the inverse association 
was weak (an $8 \%$ reduction in risk per $100 \mathrm{mg}$ magnesium/day increment). Likewise, a previous meta-analysis found that magnesium intake was non-significantly inversely associated with coronary heart disease with a pooled RR ( $95 \%$ confidence intervals (CIs)) of 0.86 (0.67 to 1.10) for the highest intake versus the lowest intake category [43]. In the current study, we found that the HR (95\% CIs) for risk of mortality due to cardiovascular disease was 0.88 (0.61 to 1.26 ) for the highest quartile intake of magnesium versus the lowest quartile intake, which is very close to that in previous studies. Several previous studies have also evaluated the associations between magnesium intake and risk of colorectal cancer and results have also not been consistent [45]. A very recent meta-analysis found that every $100 \mathrm{mg} /$ day increase in magnesium intake was related to $12 \%$ reduced risk of colorectal cancer (RR: 0.88 ; $95 \%$ CI 0.81 to 0.97 ). In the current study, we found that the HR ( $95 \%$ CIs) for risk of mortality due to colorectal cancer was 0.76 (0.15 to 3.86) for the highest quartile intake of magnesium versus the lowest quartile intake, which is also consistent with those from previous cohort studies. The significant interaction between serum vitamin $\mathrm{D}$ and magnesium intake in relation to mortality for cardiovascular disease and colorectal cancer may also explain some inconsistencies in previous studies which examined the associations of magnesium intake alone with risk of cardiovascular disease and colorectal cancer.

A strength of our study is that it is based on NHANES, a population-based study with nationally representative samples. As with all prevalent case-control studies, one concern is that the temporal sequence may not be clear. However, it is unlikely that serum vitamin D status led to high or low intake of magnesium or vitamin D. Furthermore, the analysis of data from the NHANES III, a population-based prospective cohort, provides additional indications that magnesium interacts with vitamin $\mathrm{D}$ in relation to mortality. It is possible that people who consumed a high level of magnesium may also have a healthy lifestyle (for example, more physical activity and higher proportion of dietary supplement users). Supplement users may consume a high level of vitamin D from supplements while outdoor physical activity is related to an increasing production of $25(\mathrm{OH}) \mathrm{D}$ from sunlight exposure. We have adjusted for physical activity and intake of vitamin D from both diet and supplement in all analyses. Furthermore, we have conducted stratified analyses by physical activity and use of supplement. We found, unlike intake of magnesium, physical activity and use of supplements did not significantly or marginally significantly modify the association between serum 25(OH)D and mortality. Finally, although multiple 24-h dietary recalls are used as a gold standard measure in nutritional epidemiologic studies, a one-time 24-h dietary recall may not capture long-term dietary exposure. However, similar to dietary vitamin D and supplemental vitamin D intake, we found both dietary intake of magnesium (based on 24-h dietary recall) and magnesium from supplementation intake (derived from 30-day supplement questionnaire) significantly contributed to serum vitamin D status. Moreover, total intake of magnesium significantly interacted with intake of vitamin $\mathrm{D}$ in relation to both magnesium deficiency and insufficiency while total intake of magnesium modified the association between serum vitamin D and mortality. Since inter-day variation in magnesium intake is random, any residual inter-day variation may lead to nondifferential misclassification, which usually biases the result to the null. Thus, the true associations of magnesium intake with vitamin D status risk may be stronger than those we observed. Our findings are not only biologically plausible, but also remarkably consistent, indicating our findings may not be solely due to chance. In the current study, we did not have data for other parameters of the vitamin $\mathrm{D} / \mathrm{PTH}$ axis (that is, serum $\mathrm{PTH}$ and 1,25-dihydroxyvitamin D), which may indeed be affected by magnesium status. Future studies are warranted to examine if low magnesium status using dietary and body status of magnesium affected both PTH levels and 1,25-dihydroxyvitamin $\mathrm{D}$ because this could serve as one mechanism for the observed interaction between serum $25(\mathrm{OH}) \mathrm{D}$ and magnesium intake on mortality.

\section{Conclusions}

Our preliminary findings indicate it is possible that magnesium intake alone or its interaction with vitamin D intake may contribute to vitamin D status. The associations between serum $25(\mathrm{OH}) \mathrm{D}$ and risk of mortality may be modified by the intake level of magnesium. Future studies, including cohort studies and clinical trials, are necessary to confirm the findings.

\section{Abbreviations}

25(OH)D: 25-Hydroxyvitamin D; 95\% Cl: 95\% confidence interval; HR: Hazard ratio; IOM: Institute of Medicine; NDI: National death index; NHANES: National Health and Nutrition Examination Survey; OR: Odds ratios; PTH: Parathyroid hormone; UVB: Ultraviolet-B; VDBP: Vitamin D binding protein.

\section{Competing interests}

The authors declare that they have no competing interests.

\section{Authors' contributions}

$X D$ and $Q D$ designed the current study and drafted the manuscript. XD carried out the statistical analysis. YS, JEM, LBS, MJS, RMN, DLS, and QD contributed to study design, data interpretation, and the critical review of the paper. All authors read and approved the final manuscript.

\section{Acknowledgements}

XD and QD were supported by R01 CA149633 (to QD) from the National Cancer Institute and R01 AT004660 (to QD) from the National Center for Complementary \& Alternative Medicine and Office of Dietary Supplements, Department of Health and Human Services and AICR \#08A074-REV (to QD) from the American Institute for Cancer Research, and Vanderbilt Institute for 
Clinical and Translational Research grant support (UL1TR000011 from NCATS/ $\mathrm{NIH})$. The funding sponsors had no role in study design, data collection, statistical analysis and result interpretation, the writing of the report, and the decision to submit for publication. We thank the investigators, the staff, and the participants of NHANES for their valuable contribution. The content is solely the responsibility of the authors and does not necessarily represent the official views of the National Cancer Institute or the National Institutes of Health.

\section{Author details}

'Department of Medicine, Division of Epidemiology, Vanderbilt University School of Medicine, Nashville, TN 37203, USA. ${ }^{2}$ Division of Preventive Medicine, Brigham and Women's Hospital, Harvard Medical School, Boston, MA 02115, USA. ${ }^{3}$ Department of Epidemiology, Harvard School of Public Health, Boston, MA 02115, USA. ${ }^{4}$ Department of Medicine, Division of Gastroenterology, Vanderbilt School of Medicine, Nashville, TN 37232, USA. ${ }^{5}$ Institute for Medicine and Public Health, Vanderbilt University Medical Center, Nashville, TN 37203, USA.

Received: 29 December 2012 Accepted: 24 July 2013

Published: 27 August 2013

\section{References}

1. Holick MF: Resurrection of vitamin D deficiency and rickets. J Clin Invest 2006, 116:2062-2072.

2. Zittermann A, lodice S, Pilz S, Grant WB, Bagnardi V, Gandini S: Vitamin D deficiency and mortality risk in the general population: a meta-analysis of prospective cohort studies. Am J Clin Nutr 2012, 95:91-100.

3. Schottker B, Ball D, Gellert C, Brenner H: Serum 25-hydroxyvitamin D levels and overall mortality. A systematic review and meta-analysis of prospective cohort studies. Ageing Res Rev 2013, 12:708-718.

4. Melamed ML, Michos ED, Post W, Astor B: 25-hydroxyvitamin D levels and the risk of mortality in the general population. Arch Intern Med 2008, 168:1629-1637.

5. Pittas AG, Lau J, Hu FB, Dawson-Hughes B: The role of vitamin D and calcium in type 2 diabetes. A systematic review and meta-analysis. J Clin Endocrinol Metab 2007, 92:2017-2029.

6. Mitri J, Muraru MD, Pittas AG: Vitamin D and type 2 diabetes: a systematic review. Eur J Clin Nutr 2011, 65:1005-1015.

7. Pittas AG, Nelson J, Mitri J, Hillmann W, Garganta C, Nathan DM, Hu FB, Dawson-Hughes B, Diabetes Prevention Program Research Group: Plasma 25-hydroxyvitamin $D$ and progression to diabetes in patients at risk for diabetes: an ancillary analysis in the Diabetes Prevention Program. Diabetes Care 2012, 35:565-573.

8. Sun Q, Shi L, Rimm EB, Giovannucci EL, Hu FB, Manson JE, Rexrode KM: Vitamin $D$ intake and risk of cardiovascular disease in US men and women. Am J Clin Nutr 2011, 94:534-542.

9. Leu M, Giovannucci E: Vitamin D: epidemiology of cardiovascular risks and events. Best Pract Res Clin Endocrinol Metab 2011, 25:633-646.

10. Giovannucci E: Epidemiological evidence for vitamin D and colorectal cancer. J Bone Miner Res 2007, 22:V81-V85.

11. Lee JE, Li H, Chan AT, Hollis BW, Lee IM, Stampfer MJ, Wu K, Giovannucci E, $\mathrm{Ma} J$ : Circulating levels of vitamin $\mathrm{D}$ and colon and rectal cancer: the Physicians' Health Study and a meta-analysis of prospective studies. Cancer Prev Res (Phila) 2011, 4:735-743.

12. Huncharek M, Muscat J, Kupelnick B: Colorectal cancer risk and dietary intake of calcium, vitamin $D$, and dairy products: a meta-analysis of 26,335 cases from 60 observational studies. Nutr Cancer 2009, 61:47-69.

13. Manson JE, Mayne ST, Clinton SK: Vitamin D and prevention of cancer ready for prime time? N Engl J Med 2011, 364:1385-1387.

14. Shapses SA, Manson JE: Vitamin D and prevention of cardiovascular disease and diabetes: why the evidence falls short. JAMA 2011, 305:2565-2566.

15. Grant WB: Effect of interval between serum draw and follow-up period on relative risk of cancer incidence with respect to 25 -hydroxyvitamin $D$ level: implications for meta-analyses and setting vitamin $D$ guidelines. Dermatoendocrinol 2011, 3:199-204.

16. Grant WB: Effect of follow-up time on the relation between prediagnostic serum 25 -hydroxyvitamin $\mathrm{D}$ and all-cause mortality rate. Dermatoendocrinol 2012, 4:198-202.

17. Manson JE, Bassuk SS, Lee IM, Cook NR, Albert MA, Gordon D, Zaharris E, Macfadyen JG, Danielson E, Lin J, Zhang SM, Buring JE: The VITamin D and OmegA-3 TriaL (VITAL): rationale and design of a large randomized controlled trial of vitamin $D$ and marine omega-3 fatty acid supplements for the primary prevention of cancer and cardiovascular disease. Contemp Clin Trials 2012, 33:159-171.

18. Mithal A, Wahl DA, Bonjour JP, Burckhardt P, Dawson-Hughes B, Eisman JA, El-Hajj Fuleihan G, Josse RG, Lips P, Morales-Torres J, IOF Committee of Scientific Advisors (CSA) Nutrition Working Group: Global vitamin D status and determinants of hypovitaminosis D. Osteoporos Int 2009, 20:1807-1820.

19. International Agency for Research on Cancer: Vitamin D and Cancer - a report of the IARC working group on vitamin D. Lyon, France: World Health Organization Press; 2008.

20. Garland CF, French CB, Baggerly LL, Heaney RP: Vitamin D supplement doses and serum 25-hydroxyvitamin $D$ in the range associated with cancer prevention. Anticancer Res 2011, 31:607-611.

21. Reddy V, Sivakumar B: Magnesium-dependent vitamin-D-resistant rickets. Lancet 1974, 1:963-965.

22. Risco F, Traba ML: Influence of magnesium on the in vitro synthesis of 24,25-dihydroxyvitamin D3 and 1 alpha, 25-dihydroxyvitamin D3. Magnes Res 1992, 5:5-14.

23. Rude RK, Adams JS, Ryzen E, Endres DB, Niimi H, Horst RL, Haddad JG Jr, Singer FR: Low serum concentrations of 1,25-dihydroxyvitamin $D$ in human magnesium deficiency. J Clin Endocrinol Metab 1985, 61:933-940.

24. Risco F, Traba ML: Possible involvement of a magnesium dependent mitochondrial alkaline phosphatase in the regulation of the 25 hydroxyvitamin D3-1 alpha-and 25-hydroxyvitamin D3-24R-hydroxylases in LLC-PK1 cells. Magnes Res 1994, 7:169-178.

25. Rosler A, Rabinowitz D: Magnesium-induced reversal of vitamin-D resistance in hypoparathyroidism. Lancet 1973, 1:803-804.

26. Sahota O, Mundey MK, San P, Godber IM, Hosking DJ: Vitamin D insufficiency and the blunted PTH response in established osteoporosis: the role of magnesium deficiency. Osteoporos Int 2006, 17:1013-1021.

27. Fuss M, Bergmann P, Bergans A, Bagon J, Cogan E, Pepersack T, Van Gossum M, Corvilain J: Correction of low circulating levels of 1,25dihydroxyvitamin $D$ by 25 -hydroxyvitamin $D$ during reversal of hypomagnesaemia. Clin Endocrinol (Oxf) 1989, 31:31-38.

28. Freedman DM, Looker AC, Abnet CC, Linet MS, Graubard BI: Serum 25-hydroxyvitamin D and cancer mortality in the NHANES III study (1988-2006). Cancer Res 2010, 70:8587-8597.

29. Michos ED, Reis JP, Post WS, Lutsey PL, Gottesman RF, Mosley TH, Sharrett AR, Melamed ML: 25-Hydroxyvitamin D deficiency is associated with fatal stroke among whites but not blacks: the NHANES-III linked mortality files. Nutrition 2012, 28:367-371.

30. [No authors listed]: Plan and operation of the Third National Health and Nutrition Examination Survey, 1988-94. Series 1: programs and collection procedures. Vital Health Stat 1 1994:1-407.

31. Centers for Disease Control and Prevention: The National Health and Nutritional Examination Survey (NHANES) Analytic and Reporting Guidelines. Atlanta, GA: CDC; 2006

32. Centers for Disease Control and Prevention: The National Health and Nutrition Examination Survey Laboratory Procedure Manual Serum 25-Hydroxyvitamin D Diasorin (formerly Incstar) 25-OH-D assay. Atlanta, GA: CDC; 2008.

33. Committee to Review Dietary Reference Intakes for Vitamin D and Calcium IOM: Implications and Special Concerns: Conclusions About Vitamin D Deficiency in the United States and Canada. In Dietary Reference Intakes for Calcium and Vitamin D. Washington, DC: National Academies Press; 2011:487.

34. Centers for Disease Control and Prevention: The National Health and Nutritiona Examination Survey Documentation, Codebook, and Frequencies, Dietary Interview - Individual Foods, First Day. Atlanta, GA: CDC; 2008.

35. Standing Committee on the Scientific Evaluation of Dietary Reference Intakes FaNBloM: Dietary Reference Intakes. In Dietary Reference Intakes for Calcium, Phosphorus, Magnesium, Vitamin D, and Fluoride. Washington, DC: National Academy Press; 17.

36. Tretli S, Schwartz GG, Torjesen PA, Robsahm TE: Serum levels of 25-hydroxyvitamin $D$ and survival in Norwegian patients with cancer of breast, colon, lung, and lymphoma: a population-based study. Cancer Causes Control 2012, 23:363-370.

37. Sakaki T, Kagawa N, Yamamoto K, Inouye K: Metabolism of vitamin D3 by cytochromes P450. Front Biosci 2005, 10:119-134.

38. Wang TJ, Jea ZFR: Common genetic determinants of vitamin $D$ insufficiency: a genome-wide association study. Lancet 2010, 376:180-188.

39. Horsting M, Deluca HF: In vitro production of 25-hydroxycholecalciferol. Biochem Biophys Res Commun 1969, 36:251-256. 
40. Haddad JG, Matsuoka LY, Hollis BW, Hu YZ, Wortsman J: Human plasma transport of vitamin D after its endogenous synthesis. J Clin Invest 1993, 91:2552-2555.

41. Gutierrez OM, Farwell WR, Kermah D, Taylor EN: Racial differences in the relationship between vitamin $\mathrm{D}$, bone mineral density, and parathyroid hormone in the National Health and Nutrition Examination Survey. Osteoporos Int 2011, 22:1745-1753.

42. Larsson SC, Orsini N, Wolk A: Dietary magnesium intake and risk of stroke: a meta-analysis of prospective studies. Am J Clin Nutr 2012, 95:362-366.

43. Song Y, Manson JE, Cook NR, Albert CM, Buring JE, Liu S: Dietary magnesium intake and risk of cardiovascular disease among women. Am J Cardiol 2005, 96:1135-1141.

44. Zhang W, Iso H, Ohira T, Date C, Tamakoshi A: Associations of dietary magnesium intake with mortality from cardiovascular disease: the JACC study. Atherosclerosis 2012, 221:587-595

45. Dai Q, Shrubsole MJ, Ness RM, Schlundt D, Cai Q, Smalley WE, Li M, Shyr Y, Zheng $W$ : The relation of magnesium and calcium intakes and a genetic polymorphism in the magnesium transporter to colorectal neoplasia risk. Am J Clin Nutr 2007, 86:743-751.

doi:10.1186/1741-7015-11-187

Cite this article as: Deng et al:: Magnesium, vitamin D status and mortality: results from US National Health and Nutrition Examination Survey (NHANES) 2001 to 2006 and NHANES III. BMC Medicine 2013 11:187.

\section{Submit your next manuscript to BioMed Central and take full advantage of:}

- Convenient online submission

- Thorough peer review

- No space constraints or color figure charges

- Immediate publication on acceptance

- Inclusion in PubMed, CAS, Scopus and Google Scholar

- Research which is freely available for redistribution 